\title{
Pigment Distribution and Total Dissolved Solids of Selected Cycles of Table Beet from a Recurrent Selection Program for Increased Pigment
}

\author{
Veronica L. Gaertner and Irwin L. Goldman ${ }^{1}$ \\ University of Wisconsin-Madison, Department of Horticulture,1575 Linden Drive, Madison, \\ WI 53706
}

\begin{abstract}
AdDitional INDEX words. Beta vulgaris, breeding, betalain, betacyanin, red beet
Abstract. Half-sib recurrent selection programs were initiated at the University of Wisconsin-Madison in 1978 and 1995 to increase betalain (betacyanin and betaxanthin) concentration in red and yellow table beets (Beta vulgaris L. ssp. vulgaris), respectively. Cycles of selection from both the red and yellow table beet breeding programs were evaluated for pigment and total dissolved solids (TDS) distribution in five tissue sections (outer, middle and center zones of the root; leaf and petiole) in two environments (early and late planting) during 2002. Betaxanthin concentration increased with the later planting date in the majority of the tissue zones in the yellow and red table beet populations. Absolute pigment concentration of the outer root zone increased the most over cycles of selection: $46.6 \mathrm{mg} / 100 \mathrm{~g}$ fresh weight (FW) betaxanthin and $201 \mathrm{mg} / 100 \mathrm{~g} \mathrm{FW}$ betacyanin for yellow and red populations, respectively. However, the greatest rate of gain was in the center and middle tissue zones. Selection based on the outer $\mathbf{2}$ cm of root tissue has effectively increased pigmentation of the entire beet plant. A correlated response to selection in leaf and petiole tissue was measured for pigment concentration in both populations. The contribution of each tissue zone to total pigment concentration of the beet plant remained constant throughout cycles of selection averaging $39 \%, 25 \%, 25 \%, 6 \%$, and $5 \%$ for outer, middle, center, petiole and leaf tissue zones, respectively. Across all table beet populations, pigment concentration of the outer root zone was $55 \%$ and $62 \%$ higher than middle and center zones, respectively. TDS of the outer root zone was $10 \%$ and $12 \%$ higher than middle and center zones, respectively.
\end{abstract}

Betalains are water-soluble, vacuolar pigments produced by select fungi and plants within select families of the Order Caryophyllales, including table beet. Betalains are created from the condensation of a primary or secondary amine (cyclodopa glucoside or 4,5-secodopa) with betalamic acid resulting in the structure of a 1,2.4,7,7-pentasubstituted 1,7-diasaheptamiethin system (Stafford, 1994; von Elbe and Goldman, 2000).

Betalains are composed of two major pigment groups: betacyanins (BC) and betaxanthins (BX). BC are produced from a condensation of betalamic acid with cyclo-dopa while $\mathrm{BX}$ result from a condensation reaction of betalamic acid with specific amino acids. $\mathrm{BC}\left(\mathrm{A}_{\max } 540 \mathrm{~nm}\right)$ produce a blue-violet hue; $\mathrm{BX}$ $\left(\mathrm{A}_{\max } 480 \mathrm{~nm}\right)$ produce a yellow hue. A ratio of both pigments contributes to the final color of the plant tissue.

High temperatures have been associated with decreased pigment content (Sistrunk and Bradley, 1970) while cooler temperatures produce beets with elevated pigment concentration (Blackmore et al., 1942). Sistrunk and Bradley (1970) found that darker beets with higher sugar content came from early spring and fall plantings vs. those from late spring. Specifically, they found that the optical densities of beets for the early spring and fall plantings were $13 \%$ and $41 \%$ higher than those of late spring plantings. Depending on the planting date, growing season length can have varying effects on total pigment concentrations (von Elbe, 1977). As growing season length increases, $\mathrm{BC}$ concentration levels off or in some cases decreases, while BX concentration continues to increase (Nilsson, 1973; Watson and Gabelman, 1982).

Received for publication 8 July 2004. Accepted for publication 28 Aug. 2004. The technical assistance of Nick Breitbach and Kathleen Quast is gratefully acknowledged.

1To whom reprint requests should be addressed.E-mail address: ilgoldma@wisc. edu
Root size and weight are negatively correlated with both pigment concentration and TDS levels (Nilsson, 1973; von Elbe, 1977; Watson and Gabelman, 1982). Watson and Gabelman (1982) found a correlation of $r=-0.24$ between root weight and TDS. Nilsson (1973) found an approximately 2-fold increase in total pigment concentration in small beets $(25-35 \mathrm{~mm}$ diameter) versus large beets $(75-85 \mathrm{~mm})$, however, beet diameter appeared to have no influence on the $\mathrm{BC}: \mathrm{BX}$ ratio. Nilsson also speculated that these changes in root weight and pigment concentration were not due to differing numbers of cambial rings.

Substantial pigment variation among various table beet genotypes has been reported in numerous studies (Nilsson, 1973; von Elbe, 1977; Watson and Gabelman, 1982). Nilsson (1973) noted significant differences among cultivars, in some cases $100 \%$ between light- and dark-colored beets, for $\mathrm{BC}, \mathrm{BX}$, and $\mathrm{BC}$ : $\mathrm{BX}$ that were not accounted for by beet size and growth season. Watson and Gabelman (1984) performed a genetic analysis for pigment concentration of breeding populations and determined that general combining ability (GCA) and specific combining ability (SCA) were significant for $\mathrm{BC}, \mathrm{BX}$, and $\mathrm{BC}$ : $\mathrm{BX}$ ratio, however, GCA effects were of more importance in determining pigment and sucrose concentration than SCA effects. Watson and Gabelman (1984) also found a genotypic correlation of $r=0.87$ and a significant phenotypic correlation of $r=0.79$ between BC and $\mathrm{BX}$ concentration.

The demands of selective consumers and more stringent FDA legislation have increased the need for natural red pigments such as betalains (Jones, 1992). However, the potential for betalains may involve more than their use as food colorants. Betalains have recently been shown to have antioxidant and phase II enzyme-inducing activity (Kanner et al., 2001; Wettasinghe et al., 2002), suggesting they are phytochemicals with potential value for human health. 
A half-sib recurrent selection program was initiated at the Univ. of Wisconsin-Madison in 1978 by Watson and Gabelman to simultaneously change pigment concentration and TDS in red table beet. Initially a selection index for pigment and TDS was utilized. Selection was accomplished for high pigment in two populations. One population was selected for both high pigment and low TDS, while the other was selected for high pigment and high TDS. These populations became known as HPHS (high-pigment, high solids) and HPLS (high-pigment, low solids). HPHS populations were developed for the canning and fresh market industry. HPLS populations were developed for natural food colorant production. Detail on the selection program used to develop these populations is provided in Goldman et al. (1996).

Solids are a limiting factor in colorant processing because they inhibit additional concentration of the colorant. Wolyn and Gabelman (1990) reported high realized heritabilities (0.81 and $0.82)$ for total pigment and lower realized heritabilties $(0.25$ and 0.27 ) for solids during the initial cycles of the program (C1-C3). Goldman et al. (1996) determined that the index selection technique initiated by Watson and Gabelman was effective for increasing pigment concentration in beet, but ineffective for altering solids levels. Due to these findings, recurrent selection became focused solely on pigment concentration. Selected families from the HPHS and HPLS populations were eventually combined and renamed Ruby Lake (C13). Cycles of selection in the red table beet populations can be classified into the following categories based on the selection criteria used at that time: 1) selection based on BC and TDS (Cycle 1-4), 2) selection based on BC:BX and TDS (Cycle 5-9) and 3) selection based on a combination of BC:BX and BC (Cycles 10-16).

Another recurrent selection program was initiated in 1996 to increase BX levels in yellow table beet. This program followed a similar selection strategy as the red table beet selection program, except selection was for high pigment only, and TDS was not measured. Recurrent selection has resulted in over $300 \%$ increase in total pigment concentration between $\mathrm{C} 1$ and $\mathrm{C} 16$ and over $250 \%$ increase in BX concentration between $\mathrm{C} 0$ and $\mathrm{C} 4$ for the red and yellow table beet populations, respectively.

Phenotypic selection in these programs was based upon the pigment concentration of cylindrical core samples $(2 \mathrm{~cm}$ length $\times 18 \mathrm{~mm}$ diameter) taken from the outer $2 \mathrm{~cm}$ of root tissue. Pigment concentration was obtained from a bulked sample of 10 individuals per half-sib family. Therefore, selection for pigment in both yellow and red table beet recurrent selection programs is based solely on the pigment concentration of the outer $2-\mathrm{cm}$ zone of the root, rather than the pigment concentration throughout the entire beet root. Observations by D.N. Breitbach (personal communication) suggested that pigment levels in the outer zone of high pigment beets were significantly higher than those in the internal layers. The objectives of this study were to determine the spatial distribution of pigment and TDS throughout root, leaf and petiole tissue of selected populations from the red and yellow recurrent selection programs. We also examined the rate of change in pigment composition across cycles of selection in two different colored table beet populations.

\section{Materials and Methods}

Plant material and experimental design. A comprehensive list of all table beet populations used in this study is presented in Table 1. Cycles 2, 4, 8, 9, and 12 (both HPHS and HPLS populations) and cycles 13 and 15 (Ruby Lake population) were chosen
Table 1. Cycle, year, and population source of yellow and red table beet populations grown at Arlington, Wis., in 2002 and evaluated for spatial distribution of pigment concentration and total dissolved solids.

\begin{tabular}{|c|c|c|c|}
\hline Color & Cycle or check cultivar & Selected year & Population \\
\hline \multirow[t]{13}{*}{ Red } & $\mathrm{C} 2^{\mathrm{z}}$ & 1983 & $\mathrm{HPHS}^{\mathrm{y}}$ \\
\hline & $\mathrm{C} 2$ & 1983 & HPLS \\
\hline & $\mathrm{C} 4$ & 1990 & HPHS \\
\hline & $\mathrm{C} 4$ & 1990 & HPLS \\
\hline & $\mathrm{C} 8$ & 1994 & HPHS \\
\hline & $\mathrm{C} 8$ & 1994 & HPLS \\
\hline & C9 & 1995 & HPHS \\
\hline & C9 & 1995 & HPLS \\
\hline & $\mathrm{C} 12$ & 1998 & HPHS \\
\hline & $\mathrm{C} 12$ & 1998 & HPLS \\
\hline & $\mathrm{C} 13$ & 1999 & Ruby Lake \\
\hline & $\mathrm{C} 15$ & 2001 & Ruby Lake \\
\hline & 'Big Red' & $\mathrm{NA}^{\mathrm{x}}$ & \\
\hline \multirow[t]{5}{*}{ Yellow } & $\mathrm{C} 0$ & 1998 & \\
\hline & $\mathrm{C} 1$ & 1999 & \\
\hline & $\mathrm{C} 2$ & 2000 & \\
\hline & $\mathrm{C} 3$ & 2001 & \\
\hline & 'Golden Boy' & NA & \\
\hline
\end{tabular}

${ }^{\mathrm{z}} \mathrm{C}$ followed by letter indicates selection cycle number

yHPHS refers to high-pigment high solids and HPLS refers to high-pigment low solids. Ruby Lake is population bred for high pigment and 'Big Red' is an $\mathrm{F}_{1}$ hybrid cultivar.

Not applicable.

from the red table beet program. Cycles were chosen to represent the different categories of selection used throughout the red table beet selection program. Individual cycles within the selection categories were chosen based on a seed germination test. Cycles 0-3 were chosen from the yellow table beet program. Bulked seed stocks were created for each cycle by combining equal volumes of seed from every half-sib family within the selected cycle, which was approximately 70 families but varied with each cycle (Goldman et al., 1996). Checks consisted of one $F_{1}$ hybrid 'Big Red' for red table beets and one open-pollinated population 'Golden Boy' for yellow table beet populations. 'Big Red' and 'Golden Boy' are the standard checks used in the red and yellow table beet recurrent selection programs.

Experiments were conducted in 2002 at The Arlington Horticultural Research Farm (Arlington, Wis.) in Plano silt loam soil. 
Experiments were conducted in two environments, consisting of an early and late planting. Eighteen beet entries (Table 1) were planted in two environments which represented two planting dates (7 May and 21 June). These experiments were harvested at two dates (8 Aug. and 10 Sept.). Plots were arranged in a splitplot design with four randomized complete blocks of entries as main plots. Tissue zones represented sub-plots. Plots consisted of single rows (3.66 m long and $46 \mathrm{~cm}$ apart) of all populations and checks. Each main plot was surrounded on two sides by two guard rows composed of one row of 'Big Red' and one row of 'Croni'. Each experiment was treated separately in the analysis of variance.

Ten randomly chosen roots from each row were harvested and topped by hand. Roots were washed, air-dried and weighed before sampling. Shoots and roots were stored at $4{ }^{\circ} \mathrm{C}$ until sampling. All tissues were sampled within $48 \mathrm{~h}$ of harvesting. Tops were sampled by separating petiole from leaf tissue at the base of the leaf. Root samples consisted of tissue cylinders obtained from the thickest portion of longitudinally-halved roots with a core borer (Fig. 1). The average beet diameter was $\approx 6 \mathrm{~cm}$. Cylinders for TDS and pigment analysis were $9 \mathrm{~cm}$ and $18 \mathrm{~cm}$ diameter, respectively. Cylinders were then divided into equal sections $(\approx 1$ $\mathrm{cm}$ thick) representing the outer, middle and center zone of the root (Fig. 1), resulting in 20 subsamples per zone per row. The samples were then stored in plastic bags at $-20^{\circ} \mathrm{C}$ until analyses were performed.

Pigment And total dissolved solids analysis. Pigment analyses followed the method of Wolyn and Gabelman (1990) with modifications. Frozen samples for pigment analysis were ground using a standard food processor and then were combined with distilled water equal to $200 \%$ of the sample weight. The mixture was homogenized for 2 min using a blender and a $15-\mathrm{mL}$ aliquot was removed. Aliquots were centrifuged $\left(31,700 g_{\mathrm{n}}\right)$ for $30 \mathrm{~min}$ at $4{ }^{\circ} \mathrm{C}$. A $25 \mu \mathrm{L}$ aliquot of the root extract supernatant $(200 \mu \mathrm{L}$ for leaf and petiole extracts) was diluted in $4 \mathrm{~mL}$ of distilled water. The absorbance of the solution was measured at 476, 538, and $600 \mathrm{~nm}$. BC and BX levels were computed as mg/100 g FW according to the method of Nilsson (1973). The BC:BX ratio was calculated as a separate variable.

TDS analysis followed the method of Wolyn and Gabelman (1990). Frozen samples were thawed to room temperature and hand-pressed within sealed plastic bags to produce fresh juice. $30 \mu \mathrm{L}$ of juice were analyzed with a refractometer to determine percent TDS.

STATISTICAL ANALYSIS. Data were initially screened for normality using the Shapiro-Wilks test $(P>0.05)$. BC and BX values for all tissue types in both red and yellow populations were transformed using either an exponential or logarithmic scale. Normalized data were subjected to an analysis of variance using the generalized linear models procedure (GLM) of the Statistical Analysis System (SAS Institute, Cary, N.C.) with a split-plot model design where tissue zone represented a subplot within table beet entries, which were considered whole plots. Red and yellow entries were analyzed separately. Means comparisons were made using least significant differences (LSD). Correlations were obtained from the correlation procedure (CORR) in SAS and were calculated on an entry mean basis.

\section{Results and Discussion}

Mean squares for date $\times$ tissue and entry $\times$ tissue interactions were highly significant for most variables in both yellow and red table beet populations excluding TDS (Tables 2 and 3). Upon further inspection, the significance of these values was found to be due to changes in magnitude of means rather than rank. Therefore, main effect means were assessed. The tissue zone and entry main effect were highly significant for BC, BX, total pigment (TP), BC:BX ratio, and TDS variables in both the yellow and red table beet populations (Table 2 and 3 ). The planting date main effect in yellow table beet populations was significant or highly significant for all variables except TP, however in red table beet populations, the planting date main effect was only highly significant for $\mathrm{BX}$ and $\mathrm{BC}: \mathrm{BX}$ ratio.

Because selection criteria, initial populations and selection intensity differed for the red and yellow table beets, the results for both populations will be discussed individually. Since red table beet selection is based primarily on BC and yellow table beet selection is based primarily on BX (yellow table beets contain only trace amounts of $\mathrm{BC}$ ), these will be the only pigment values that are addressed in detail for each population.

EFFECT OF TISSUE ZONE AND CYCLE OF SELECTION ON PIGMENT CONCENTRATION IN RED TABLE BEET. BC concentration in HPLS populations increased significantly $(P<0.05)$ over selection cycles in the outer tissue zone (Table 4). BC increased over selection cycles in middle, center, petiole and leaf tissue zones; however, these increases were not significant for every selected cycle. The greatest absolute increase in $\mathrm{BC}$ concentration from $\mathrm{C} 2-\mathrm{C} 12$ was in the outer tissue zone $(150 \mathrm{mg} / 100 \mathrm{~g} \mathrm{FW})$. In HPLS populations, $\mathrm{BC}$ increased at an average rate of $14.5 \%, 19.8 \%, 19.6 \%, 8.2 \%$, and $5 \%$ per cycle between $\mathrm{C} 2-\mathrm{C} 12$ for outer, middle, center, petiole and leaf tissue, respectively. Wolyn and Gabelman (1990) determined gain per cycle for TP between $\mathrm{C} 1-\mathrm{C} 3$ was $18.4 \%$. The relative similarity of gain per cycle when comparing rates from $\mathrm{C} 1-\mathrm{C} 3$ with rates from $\mathrm{C} 2-\mathrm{C} 12$ suggests that alleles responsible for

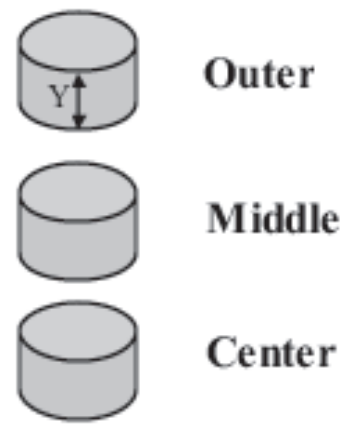

Fig. 1. Diagram of tissue zone samples taken for pigment and total dissolved solids (TDS) analysis. Cylinders were taken from the thickest portion of the root and then divided into equal thirds to create outer, middle, and center tissue zones. The diameter of cylinder samples (X) was 9 and $18 \mathrm{~mm}$ for TDS and pigment analysis, respectively. The thickness of each of the zones from cylinders $(\mathrm{Y})$ was $\approx 1 \mathrm{~cm}$. pigment concentration in HPLS populations have yet to be fixed and that gains from selection are still possible.

BC concentration in HPHS and Ruby Lake populations increased significantly $(P>0.05)$ in the outer tissue zone in every cycle except between $\mathrm{C} 2-\mathrm{C} 4$ and between C12-C13 (Table 5). BC increased across middle, center, petiole and leaf tissue zones over the majority of the cycles. BC increased by $187 \%, 239 \%, 223 \%, 107 \%$, and $97 \%$ between $\mathrm{C} 2-\mathrm{C} 12$ in outer, 
Table 2. Mean squares from the analysis of variance for analysis of betacyanin (BC) and betaxanthin (BX) pigment distribution and total dissolved solids (TDS) in red table beet populations selected for increased pigment evaluated at Arlington, Wis., in 2002.

\begin{tabular}{|c|c|c|c|c|c|c|}
\hline \multirow[b]{2}{*}{ Source of variation } & \multirow[b]{2}{*}{$\mathrm{df}$} & \multicolumn{5}{|c|}{ Mean square } \\
\hline & & $\mathrm{BC}$ & $\mathrm{BX}$ & Total & $\mathrm{BC}: \mathrm{BX}$ ratio & $\mathrm{TDS}^{\mathrm{z}}$ \\
\hline Replicate & 3 & 0.26 & $0.61 * *$ & $2655.51 * * *$ & $41.28 * *$ & $10.75 * * *$ \\
\hline Entry (E) & 12 & $5.42 * * *$ & $3.60 * * *$ & $67461.26^{* * *}$ & $53.61 * * *$ & $47.00 * * *$ \\
\hline Tissue zone (T) & 4 & $57.47 * * *$ & $482.84 * * *$ & $827095.43 * * *$ & $5549.47 * * *$ & $43.99 * * *$ \\
\hline $\mathrm{E} \times \mathrm{T}$ & 48 & $0.20 * *$ & $0.98 * * *$ & $9793.97 * * *$ & $19.65 * * *$ & 0.64 \\
\hline Planting date (D) & 1 & 0.00 & $9.91 * * *$ & 950.27 & $151.14 * * *$ & 0.16 \\
\hline $\mathrm{D} \times \mathrm{E}$ & 12 & $0.22 *$ & 0.21 & 552.05 & 11.78 & 2.00 \\
\hline $\mathrm{D} \times \mathrm{T}$ & 4 & $1.54 * * *$ & $3.06 * * *$ & $2791.24 * * *$ & $48.89 * * *$ & 1.97 \\
\hline $\mathrm{D} \times \mathrm{E} \times \mathrm{T}$ & 16 & 0.10 & $0.21 *$ & 236.68 & $14.59 * * *$ & 0.62 \\
\hline
\end{tabular}

zTDS data were collected from three tissue zones.

*,***** Significant at $P \leq 0.05,0.01$, or 0.001 , respectively.

Table 3. Mean squares from the analysis of variance for analysis of betacyanin (BC) and betaxanthin (BX) pigment distribution and total dissolved solids (TDS) in yellow table beet populations selected for increased pigment evaluated at Arlington,Wis., in 2002.

\begin{tabular}{|c|c|c|c|c|c|}
\hline \multirow[b]{2}{*}{ Source of variation } & \multirow[b]{2}{*}{ df } & \multicolumn{4}{|c|}{ Mean square } \\
\hline & & $\mathrm{BC}$ & $\mathrm{BX}$ & Total & $\operatorname{TDS}^{\mathrm{z}}$ \\
\hline Replicate & 3 & 4.05 & $19.19^{*}$ & $92.30 * *$ & $4.51^{*}$ \\
\hline Entry (E) & 4 & $134.13 * * *$ & $349.82 * * *$ & $3334.55 * * *$ & $27.94 * * *$ \\
\hline Tissue zone (T) & 4 & $1293.00 * * *$ & $3476.13 * * *$ & $14412.46^{* * *}$ & $22.12 * * *$ \\
\hline $\mathrm{E} \times \mathrm{T}$ & 16 & $59.60 * * *$ & $83.81 * * *$ & $636.53 * * *$ & 0.28 \\
\hline Planting date (D) & 1 & $68.36^{* * *}$ & $24.63^{*}$ & 66.57 & $14.98 * *$ \\
\hline $\mathrm{D} \times \mathrm{E}$ & 4 & 9.24 & $20.00^{* *}$ & $138.51 * * *$ & 3.02 \\
\hline $\mathrm{D} \times \mathrm{T}$ & 4 & 8.85 & 10.76 & $153.76^{* * *}$ & 0.24 \\
\hline $\mathrm{D} \times \mathrm{E} \times \mathrm{T}$ & 16 & 5.69 & $12.51 * * *$ & 24.50 & 0.37 \\
\hline
\end{tabular}

middle, inner, petiole, and leaf zones, respectively (Fig. 2A). The greatest change in absolute BC between C2-C15 in HPHS/Ruby Lake populations was in the outer tissue zone $(201 \mathrm{mg} / 100 \mathrm{~g}$ FW). BC concentration increased at an average rate of $14.4 \%$, $18.4 \%, 17.2 \%, 8.2 \%$, and $7.5 \%$ per cycle between $\mathrm{C} 2-\mathrm{C} 15$ for outer, middle, center, petiole and leaf tissue zones, respectively. Wolyn and Gabelman (1990) determined a $22.2 \%$ rate of gain per cycle for $\mathrm{C} 1-\mathrm{C} 3$ in HPHS.

BX concentration also increased in all tissue zones over cycles of selection (Fig. 2B). In HPHS/Ruby Lake populations, the largest increase in BX between $\mathrm{C} 2-\mathrm{C} 15$ was in the center tissue zone $(35.25 \mathrm{mg} / 100 \mathrm{~g} \mathrm{FW})$. Between C2-C15, BX increased by $50 \%$, $112 \%, 153 \%, 131 \%$, and $35 \%$ for outer, middle, center, petiole and leaf tissue zones, respectively. The greatest increase in absolute $\mathrm{BX}$ was in the center tissue zone $(35 \mathrm{mg} / 100 \mathrm{~g} \mathrm{FW})$.
The outer tissue zone contained the highest TP levels of all five tissue zones evaluated (Fig. 2C). On average, pigment concentration of the outer root zone was 55\% and $62 \%$ higher than middle and center zones, respectively. However, the relative total pigment concentration of each tissue zone remained constant throughout cycles of selection, averaging $39 \%, 25 \%, 25 \%, 6 \%$, and $5 \%$ for outer, middle, center, petiole and leaf tissue zones, respectively. This finding reveals that selection based on the outer $2 \mathrm{~cm}$ of root tissue has effectively increased pigmentation of the entire beet plant.

Pigment concentration data indicate a correlated response to selection for BC and BX in leaf and petiole tissue (Tables 4 and 5). Although middle and center tissue zones increased in pigment concentration over cycles of selection it would be incorrect to report this increase as a correlated response to selection since the 
Table 4. Betacyanin and betaxanthin pigment distribution for five tissue zones over five cycles of selection, C2, C4, C8, C9, and C12, in high-pigment low solids (HPLS) red table beet populations grown at Arlington, Wis., In 1992.

Pigment concn (mg/100 g FW)

\begin{tabular}{|c|c|c|c|c|c|c|c|c|c|c|}
\hline \multirow[b]{2}{*}{ Entry } & \multicolumn{5}{|c|}{ Betacyanin } & \multicolumn{5}{|c|}{ Betaxanthin } \\
\hline & Outer $^{\mathrm{z}}$ & Middle & Center & Petiole & Leaf & Outer & Middle & Center & Petiole & Leaf \\
\hline $\mathrm{C} 2^{\mathrm{y}}$ & 103.06 & 55.88 & 55.60 & 17.29 & 9.73 & 33.58 & 22.67 & 22.87 & 1.22 & 2.17 \\
\hline $\mathrm{C} 4$ & 127.22 & 75.64 & 65.80 & 22.40 & 12.96 & 42.99 & 31.27 & 28.99 & 1.45 & 2.23 \\
\hline $\mathrm{C} 8$ & 158.78 & 92.60 & 87.36 & 25.08 & 14.39 & 41.22 & 32.76 & 36.05 & 1.32 & 2.20 \\
\hline C9 & 165.20 & 99.09 & 98.58 & 30.08 & 17.31 & 39.82 & 33.91 & 40.10 & 1.63 & 2.25 \\
\hline $\mathrm{C} 12$ & 252.56 & 166.65 & 164.57 & 33.86 & 18.55 & 57.19 & 48.70 & 58.56 & 1.47 & 2.68 \\
\hline 'Big Red'x & 96.06 & 63.36 & 55.96 & 31.48 & 14.55 & 31.42 & 23.09 & 21.40 & 2.61 & 2.63 \\
\hline LSD 0.05 & 22.12 & 22.86 & 11.99 & 5.25 & 2.48 & 6.17 & 6.70 & 5.41 & 0.57 & 0.70 \\
\hline LSD 0.01 & 29.66 & 30.65 & 16.07 & 7.04 & 3.33 & 8.27 & 9.00 & 7.25 & 0.76 & 0.93 \\
\hline
\end{tabular}

${ }^{2}$ Outer, middle and center refer to concentric zones of the beetroot.

${ }^{\mathrm{C}}$ followed by a number indicates cycle number.

${ }^{x}$ Check is $\mathrm{F}_{1}$ hybrid 'Big Red'.

Table 5. Pigment distribution for five tissues zones over seven cycles of selection (C2, C4, C8, C9, C12, C13, and C15) in high-pigment high solids (HPHS) and high-pigment low solids (HPLS) red table beet populations grown at Arlington, Wis., In 1992.

Pigment concn (mg/100 g FW)

\begin{tabular}{|c|c|c|c|c|c|c|c|c|c|c|}
\hline \multirow[b]{2}{*}{ Entry } & \multicolumn{5}{|c|}{ Betacyanin } & \multicolumn{5}{|c|}{ Betaxanthin } \\
\hline & Outer $^{z}$ & Middle & Center & Petiole & Leaf & Outer & Middle & Center & Petiole & Leaf \\
\hline $\mathrm{C} 2^{\mathrm{y}}$ & 107.24 & 63.32 & 58.99 & 18.98 & 10.43 & 36.24 & 23.53 & 22.86 & 1.13 & 2.25 \\
\hline $\mathrm{C} 4$ & 129.19 & 75.79 & 72.60 & 21.35 & 11.71 & 43.64 & 29.82 & 29.60 & 0.97 & 1.74 \\
\hline $\mathrm{C} 8$ & 196.36 & 137.10 & 118.57 & 26.66 & 14.46 & 44.78 & 37.74 & 37.19 & 1.27 & 2.49 \\
\hline C9 & 225.68 & 130.17 & 120.77 & 30.04 & 16.56 & 54.21 & 39.21 & 43.18 & 1.59 & 2.88 \\
\hline $\mathrm{C} 12$ & 251.02 & 149.46 & 149.77 & 31.68 & 14.82 & 49.90 & 41.72 & 48.20 & 1.52 & 2.88 \\
\hline C13 & 246.66 & 175.79 & 160.36 & 31.31 & 16.16 & 56.75 & 52.30 & 58.11 & 1.65 & 2.35 \\
\hline $\mathrm{C} 15$ & 308.24 & 214.70 & 190.70 & 39.31 & 20.56 & 54.26 & 49.97 & 57.83 & 2.61 & 3.04 \\
\hline 'Big Red' x & 96.06 & 63.36 & 55.96 & 31.48 & 14.55 & 31.42 & 23.09 & 21.40 & 2.61 & 2.63 \\
\hline LSD 0.05 & 22.12 & 22.86 & 11.99 & 5.25 & 2.48 & 6.17 & 6.70 & 5.41 & 0.57 & 0.70 \\
\hline LSD 0.01 & 29.66 & 30.65 & 16.07 & 7.04 & 3.33 & 8.27 & 9.00 & 7.25 & 0.76 & 0.93 \\
\hline
\end{tabular}

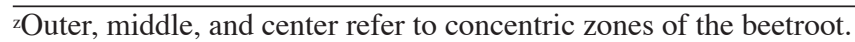

${ }^{\mathrm{y}} \mathrm{C}$ followed by letter indicates selection cycle number.

'Check is 'Big Red'.

2-cm length used for selection each cycle could have belonged to a combination of outer, middle and center zones depending on the diameter of beets.

These results also confirm previous observations that the outer tissue zone contains the greatest pigment concentration. The biology behind this phenomenon could be related to the fact that the newest growth in the cambia of the beet occurs in the outermost region of a growing beet. Therefore, the smaller cells that are within this new growth could possess a higher concentration of vacuolar metabolites including pigment and TDS (Rapoport and Loomis, 1986).

EFFECT OF TISSUE ZONE AND CYCLES OF SELECTION ON TDS IN RED TABLE BEET. Average TDS levels in the outer zone of red table beets were $8.4 \%$ and $11.6 \%$ higher than middle and center tissue zones, respectively. TDS levels in HPLS populations increased in all tissue zones over most cycles of selection, despite selective pressures to decrease solids levels (Table 6). TDS levels increased at an average rate of $2.2 \%, 2.5 \%$, and $3.5 \%$ per cycle for outer, 

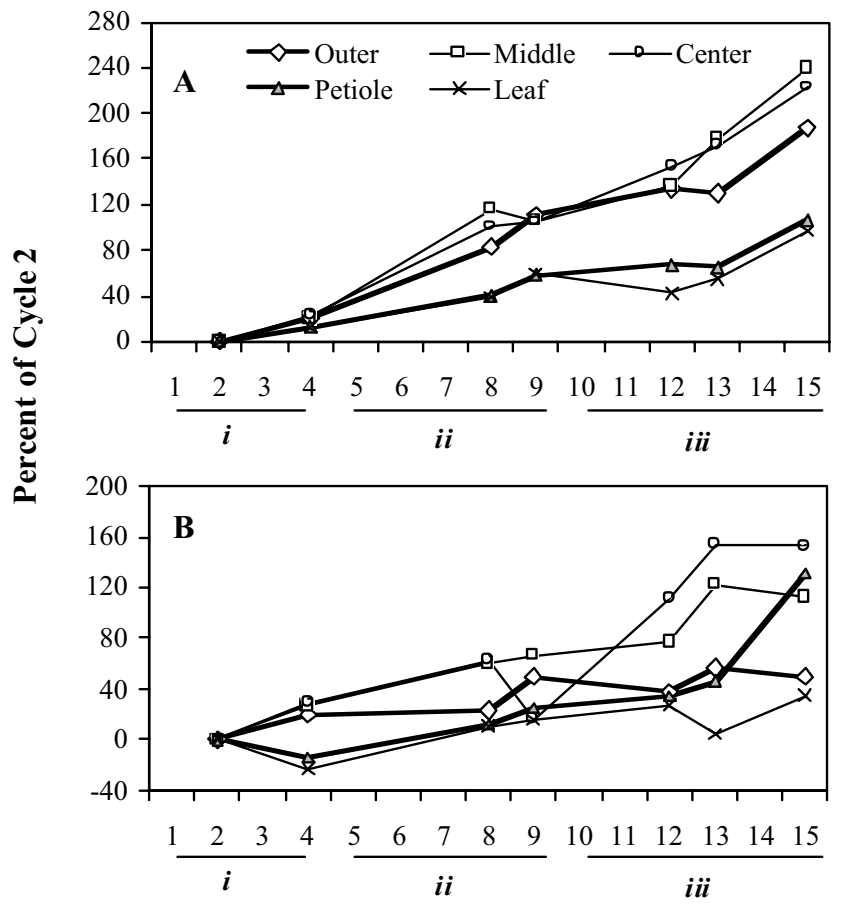

Cycle of Selection
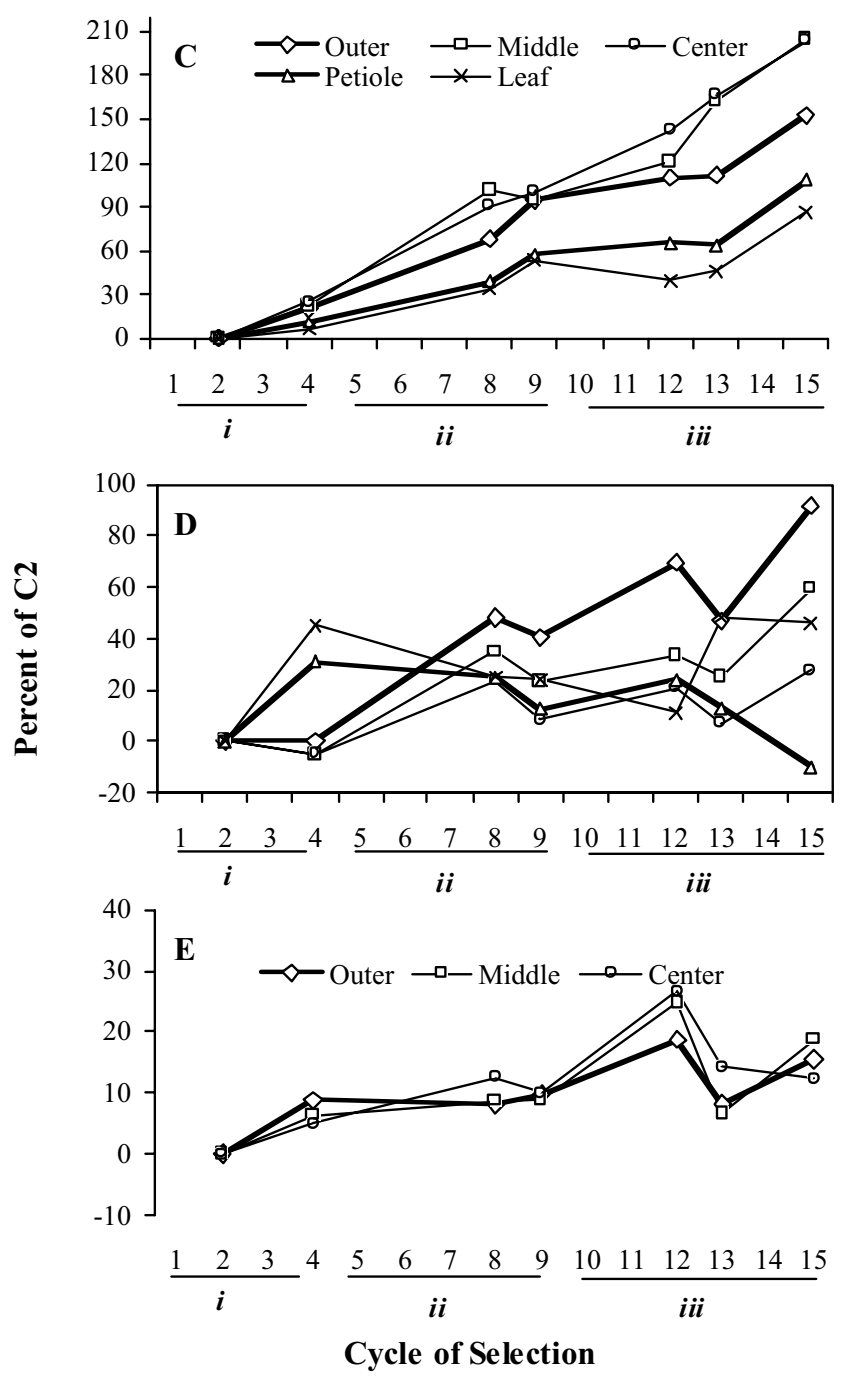

middle, and center tissue zones, respectively. These results conflict with Wolyn and Gabelman (1990) who determined the gain per cycle for solids in HPLS was actually $-2.6 \%$ from $\mathrm{C} 1-\mathrm{C} 3$. One could possibly attribute these discrepancies in gain per cycle to the fact that the data used in this study came from beets evaluated in a single year, while data for Wolyn and Gabelman's study came from cycle evaluations in three separate years. Environmental variation could have been a factor in this discrepancy. TDS levels in HPLS populations for outer, middle and center tissue zones increased 22\%, 25\%, and 35\%, respectively, between C2 and C12. These results are consistent with Goldman et al. (1996) who determined that simultaneous selection for increased pigment and decreased solids was ineffective.

In HPHS populations, TDS levels increased 19\%, 25\%, and $27 \%$ between $\mathrm{C} 2$ and $\mathrm{C} 12$ in outer, middle and center tissue zones (Table 6). These increases came about from an average gain per cycle of $1.9 \%, 2.5 \%$, and $2.6 \%$ increase in TDS levels per cycle between C2 and C12. Wolyn and Gabelman (1990) found relative solids levels increased $3.0 \%$ per cycle between $\mathrm{C} 1$ and C3. TDS levels in HPHS populations peaked in $\mathrm{C} 12$ at $14.31 \%$, $14.03 \%$, and $13.68 \%$ for outer, middle and center tissue zones, respectively. The decrease of TDS in C13 is most probably the result of combining the HPLS and HPHS populations into the Ruby Lake population (Fig. 2E).

EFFECT OF ENVIRONMENT (PLANTING DATE) ON PIGMENT CONCENTRATION AND TDS IN RED TABLE BEET. BX concentration of most tissue zones increased in the later planting date (Table 7), except those in the petioles, which decreased in the later planting date. The greatest increase in BX between planting dates occurred in the outer zone (20.2 mg/100 g FW). Average BX was $58 \%, 31 \%$, and $26 \%$ higher in outer, middle and center tissue zones from the second planting date compared to tissue zones from the early planting date (Table 9). These data are consistent with Watson and Gabelman (1982) who found a 54\% greater BX concentration in beets grown at a later planting date. Nilsson (1973) also found increased BX concentration in beets sown at a later planting date, and speculated that this was due to decreased night temperatures occurring during later plantings. Climatic data for the early and late planting date in this study reveal that average overall, minimum and maximum daily temperatures were higher in the later planting date than in the early planting date; however, these data do not reflect night temperatures alone (data not shown). Climatic data reveal that average precipitation was greater at the early planting date. It is possible that the lack of rain could have stressed the plants, resulting in more pigment production. Alternatively the reduced rainfall could have reduced moisture levels the vacuoles of beet cells, resulting in increased pigment concentration.

$\mathrm{BC}$ concentration decreased in the later planting date in most tissue zones (Table 7), except in the outer zone where $\mathrm{BC}$ remained stable over both planting dates and leaf tissue where BC increased in the later planting. The greatest decrease in $\mathrm{BC}$ between planting dates occurred in the center tissue zone (12 mg/100 g FW). TDS levels were also consistently lower in beets from the later planting

Fig. 2. Response to selection across all five tissue zones over cycles of selection for increased pigment in HPHS/Ruby Lake table beet populations between cycles 2 and 16 (C2-C16) as a percent of Cycle 2 (C2). (A) Gains in betacyanin (BC). (B) Gains in betaxanthin (BX). (C) Gains in total pigment (TP). (D) Gains in BC:BX. (E) Gains in total dissolved solids (TDS). Roman numerals represent the following selection categories: $i$ ) selection based on BC and TDS (Cycles 1-4), ii) selection based of BC:BX and TDS (Cycles 5-9) and iii) selection based on a combination of BC:BX and BC (Cycles 10-16). 
Table 6. Total dissolved solids distribution in three tissues zones over seven cycles of selection.

Total dissolved solids $(\%)$

HPHS

\begin{tabular}{|c|c|c|c|c|c|c|}
\hline Entry & Outer $^{2}$ & Middle & Center & Outer & Middle & Center \\
\hline $\mathrm{C} 2^{\mathrm{y}}$ & 12.06 & 11.25 & 10.81 & 10.59 & 9.55 & 9.03 \\
\hline $\mathrm{C} 4$ & 13.13 & 11.96 & 11.36 & 10.58 & 9.50 & 9.29 \\
\hline $\mathrm{C} 8$ & 13.03 & 12.24 & 12.16 & 11.51 & 9.91 & 9.58 \\
\hline $\mathrm{C} 9$ & 13.24 & 12.26 & 11.89 & 10.11 & 9.60 & 9.26 \\
\hline $\mathrm{C} 12$ & 14.31 & 14.03 & 13.68 & 12.90 & 11.98 & 12.18 \\
\hline C13 & 13.05 & 12.00 & 12.35 & & & \\
\hline $\mathrm{C} 15$ & 13.93 & 13.36 & 12.13 & & & \\
\hline 'Big Red' x & 12.80 & 11.48 & 11.25 & & & \\
\hline LSD 0.05 & 1.35 & 1.14 & 1.15 & 1.35 & 1.14 & 1.15 \\
\hline LSD 0.01 & 1.81 & 1.53 & 1.53 & 1.81 & 1.53 & 1.53 \\
\hline
\end{tabular}

zOuter, middle, and center refer to concentric zones of the beetroot. $\mathrm{yC}$ followed by letter indicates selection cycle number.

xCheck is 'Big Red'.

date than from the first, however, all TDS differences between planting dates were nonsignificant (data not shown).

CORRELATIONS AMONG ROOT WEIGHT, TDS, AND PIGMENT CONCENTRATION IN RED TABLE BEET. Phenotypic correlations reveal a significant relationship between BC, BX, and TDS levels at both planting dates (Table 8 ). Correlations between $\mathrm{BC}$ and $\mathrm{BX}$ were highly positive at both planting dates with $r=0.92$ for the late planting date. Although Watson and Gabelman (1984) found a similar phenotypic correlation $(r=0.79)$ between BC and BX, Watson and Gabelman (1982) found slightly different correlation values than presented in these studies $(r=0.53$ and 0.75 for early and late planting dates, respectively). Correlations between TDS and $\mathrm{BC}$ or $\mathrm{BX}$ were also positive and ranged from $r=0.39$ to $r=0.59$ at both planting dates. Inconsistencies of correlations between the two planting dates may be due to numerous climatic differences and the resulting differences in root weight (data not shown). Root weight and BC or $\mathrm{BX}$ correlations in this study were not as significant as those found in 1982 by Watson and Gabelman ( $r=-0.23$ and $r=-0.44$, for late and early dates, respectively). The only significant correlation between root weight and pigment in this study was $r$ $=-0.15$ between $\mathrm{BC}$ and root weight for the early planting date. The range of correlations between TDS and $\mathrm{BC}$ or $\mathrm{BX}$ for both planting dates was also lower $(r=0.03$ to $r=0.38)$ than the Watson and Gabelman (1982) study.

EFFECT OF TISSUE ZONE AND CYCLE OF SELECTION ON PIGMENT CONCENTRATION IN YELLOW TABLE BEET. BX concentration in the outer zone increased significantly over every cycle of selection except between C2-C3 (Table 9). BX increased in middle, center, petiole and leaf tissues over each cycle, however, these increases were not significant for every cycle of selection. The average gain per cycle between $\mathrm{C} 0-\mathrm{C} 3$ was $32.8 \%, 18.1 \%, 20.0 \%$, $37.0 \%$, and $15.0 \%$ for outer, middle, center, petiole, and leaf tissue zones, respectively (Fig. 3B). These increases are substantially higher than those achieved between $\mathrm{C} 1-\mathrm{C} 3$ for red table beets (Tables 4 and 5; Wolyn and Gabelman, 1990). This change in average gain may be due to differences in selection intensity or genetic composition within the initial yellow beet populations versus the initiation populations for the red table beet populations. The initial yellow beet populations came from a cross of a red beet with high BX from the HPLS population

Table 7. Betacyanin and betaxanthin pigment distribution means averaged over all cycles in yellow and red table beet populations grown in Summer 2002 at Arlington, Wis., in five tissue zones over two planting dates.

\begin{tabular}{|c|c|c|c|c|c|c|c|c|c|c|c|}
\hline \multirow[b]{3}{*}{ Color } & \multirow{3}{*}{$\begin{array}{l}\text { Planting } \\
\text { date }\end{array}$} & \multicolumn{10}{|c|}{ Pigment concn (mg/100 g FW) } \\
\hline & & \multicolumn{5}{|c|}{ Betacyanin } & \multicolumn{5}{|c|}{ Betaxanhin } \\
\hline & & Outer $^{\mathrm{z}}$ & Middle & Center & Petiole & Leaf & Outer & Middle & Center & Petiole & Leaf \\
\hline \multirow[t]{4}{*}{ Yellow } & Early & 1.56 & 0.85 & 0.77 & 0.81 & 0.84 & 59.02 & 23.57 & 21.90 & 12.52 & 6.82 \\
\hline & Late & 2.08 & 1.73 & 1.60 & 0.58 & 0.99 & 52.87 & 25.62 & 25.37 & 14.24 & 9.34 \\
\hline & LSD 0.05 & 0.26 & 0.21 & 0.23 & 0.07 & 0.14 & 4.56 & 1.70 & 2.97 & 2.21 & 1.80 \\
\hline & LSD 0.01 & 0.37 & 0.29 & 0.32 & 0.10 & 0.20 & 6.31 & 2.35 & 4.10 & 3.06 & 2.49 \\
\hline \multirow[t]{4}{*}{ Red } & Early & 182.14 & 120.25 & 113.68 & 30.79 & 13.27 & 34.97 & 31.08 & 34.39 & 1.60 & 2.43 \\
\hline & Late & 182.06 & 110.44 & 101.65 & 24.52 & 16.30 & 55.19 & 40.73 & 43.29 & 1.46 & 2.46 \\
\hline & LSD 0.05 & 7.32 & 9.56 & 5.35 & 2.20 & 2.07 & 2.95 & 3.18 & 2.17 & 0.25 & 0.29 \\
\hline & LSD 0.01 & 9.80 & 12.80 & 7.16 & 2.95 & 2.77 & 3.95 & 4.26 & 2.90 & 0.34 & 0.38 \\
\hline
\end{tabular}

zOuter, middle, and center refer to concentric zones of the beetroot. 
Table 8. Pearson correlation coefficients $(r)$ and statistical probabilities for weight, total dissolved solids (TDS), and betacyanin (BC) and betaxanthin (BX) pigment concentration of all red and yellow table beet populations evaluated for spatial distribution of pigment concentration and total dissolved solids.

\begin{tabular}{|c|c|c|c|c|c|c|c|}
\hline \multirow{2}{*}{ Trait } & \multirow{2}{*}{$\begin{array}{c}\text { Planting } \\
\text { Date }\end{array}$} & \multicolumn{3}{|c|}{ Red } & \multicolumn{3}{|c|}{ Yellow } \\
\hline & & Root wt (g) & $\mathrm{BC}^{\mathrm{z}}$ & $\mathrm{BX}$ & Root wt (g) & $\mathrm{BC}$ & $\mathrm{BX}$ \\
\hline \multirow[t]{2}{*}{$\mathrm{BC}$} & Early & $-0.15^{*}$ & & & -0.19 & & \\
\hline & Late & -0.09 & & & -0.17 & & \\
\hline \multirow[t]{2}{*}{$\mathrm{BX}$} & Early & -0.02 & $0.87 * *$ & & -0.20 & $0.79 * *$ & \\
\hline & Late & -0.02 & $0.92 * *$ & & $-0.34 * *$ & $0.80 * *$ & \\
\hline \multirow[t]{2}{*}{$\operatorname{TDS}^{\mathrm{y}}$} & Early & $-0.22 * *$ & $0.58 * *$ & $0.39 * *$ & $-0.55 * *$ & $0.63 * *$ & $0.63 * *$ \\
\hline & Late & -0.04 & $0.59 * *$ & $0.52 * *$ & $-0.26^{*}$ & $0.54 * *$ & $0.52 * *$ \\
\hline
\end{tabular}

${ }^{2} \mathrm{BC}$ and $\mathrm{BX}$ were measured as milligrams per $100 \mathrm{~g}$ fresh weight.

*,** Significant at $P=0.05$ and 0.01 , respectively; $\mathrm{n}=52$ and 20 for red and yellow beets, respectively.

Table 9. Betacyanin and betaxanthin pigment distribution of five tissue zones in three cycles of selection, C0-C3, of yellow table beet populations grown at Arlington, Wis., in 1992.

\begin{tabular}{|c|c|c|c|c|c|c|c|c|c|c|}
\hline \multirow[b]{3}{*}{ Entry } & \multicolumn{10}{|c|}{ Pigment concn (mg/100 g FW) } \\
\hline & \multicolumn{5}{|c|}{ Betacyanin } & \multicolumn{5}{|c|}{ Betaxanthin } \\
\hline & Outer $^{z}$ & Middle & Center & Petiole & Leaf & Outer & Middle & Center & Petiole & Leaf \\
\hline $\mathrm{C}^{\mathrm{y}}$ & 1.06 & 0.94 & 0.79 & 0.54 & 0.91 & 35.53 & 18.77 & 18.02 & 7.99 & 6.62 \\
\hline $\mathrm{C} 1$ & 1.89 & 1.46 & 1.42 & 0.71 & 0.94 & 53.27 & 22.56 & 22.09 & 13.99 & 7.47 \\
\hline $\mathrm{C} 2$ & 2.28 & 1.42 & 1.22 & 0.84 & 0.87 & 78.41 & 29.82 & 27.42 & 19.62 & 9.25 \\
\hline $\mathrm{C} 3$ & 2.75 & 1.69 & 1.69 & 0.84 & 0.89 & 82.16 & 32.36 & 32.41 & 19.82 & 10.61 \\
\hline Check $^{\mathrm{x}}$ & 1.1 & 0.94 & 0.82 & 0.54 & 0.95 & 30.35 & 19.47 & 18.22 & 5.49 & 6.45 \\
\hline LSD 0.05 & 0.34 & 0.53 & 0.39 & 0.11 & 0.23 & 10.63 & 4.49 & 5.86 & 3.19 & 2.18 \\
\hline LSD 0.01 & 0.54 & 0.74 & 0.55 & 0.15 & 0.33 & 14.91 & 6.29 & 8.21 & 4.47 & 3.06 \\
\hline
\end{tabular}

${ }^{\mathrm{z}}$ Outer, middle, and center refer to concentric zones of the beetroot.

yCheck is 'Golden Boy'.

${ }^{\mathrm{x}} \mathrm{C}$ followed by a number indicates cycle number.

and 'Burpee's Golden', which has a very low BX concentration. Net increases in BX were $131 \%, 72 \%, 80 \%, 148 \%$, and $60 \%$ between $\mathrm{C} 0-\mathrm{C} 3$ in outer, middle, center, petiole, and leaf zones, respectively (Fig. 3B). The greatest change in BX levels over cycles of selection was in the outer tissue zone $(46.63 \mathrm{mg} / 100$ g FW). BC levels were substantially lower than BX levels. BC increased over cycles of selection in all tissue zones with the greatest change in $\mathrm{BC}$ between $\mathrm{C} 0-\mathrm{C} 3$ occurring in the outer tissue zone (1.69 mg/100 g FW) (Fig. 3A).

EFFECT OF TISSUE ZONE AND CYCLES OF SELECTION ON TDS IN YELLOW TABLE BEET. TDS levels in the outer zone were 11.0\% and $13.2 \%$ higher than middle and center tissue zones, respectively. TDS levels in the outer tissue zone significantly $(P>0.05)$ increased over cycles of selection except between $\mathrm{C} 1-\mathrm{C} 2$ where TDS decreased (Table 10). TDS levels in middle and center tissue zones increased over cycles of selection, however, increases were not significant for every cycle of selection. The average gain per cycle was $5.1 \%, 4.1 \%$, and $4.7 \%$ for outer, middle and center tissue zones, respectively. The greatest increase in TDS between $\mathrm{C} 0-\mathrm{C} 3$ occurred in the outer tissue zone $(2.22 \%)$.

EFFECT OF PLANTING DATE ON PIGMENT CONCENTRATION AND TDS in yeLLOW TABLE BEET. Average BX levels of most tissue zones increased in the later planting date (Table 7), with the exception of average BX levels in the outer tissue zone, which decreased with the later planting date. Average BX was 9\%, $16 \%, 14 \%$, and $37 \%$ higher in middle, center, petiole, and leaf tissue zones from the second planting date compared to tissue zones from the early planting date. Although these data are generally consistent with previous experiments (Nilsson, 1973; Watson and Gabelman, 1982), decreased temperatures cannot explain the increase in BX at the later planting date as has been the explanation for these results in previous studies. 


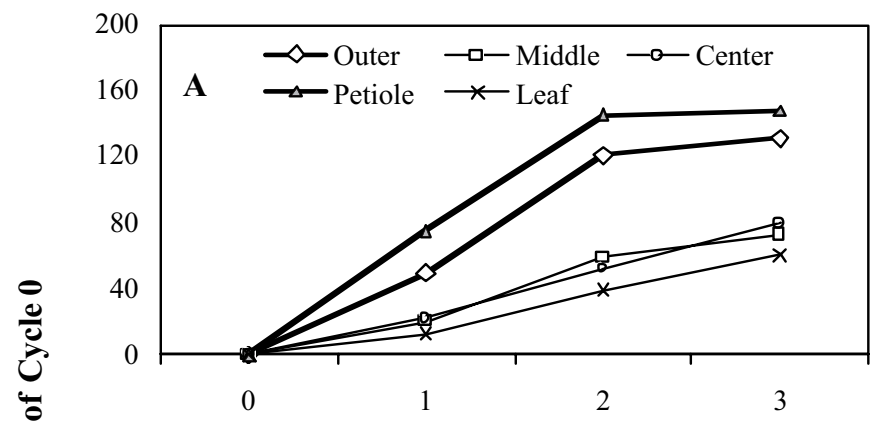

:

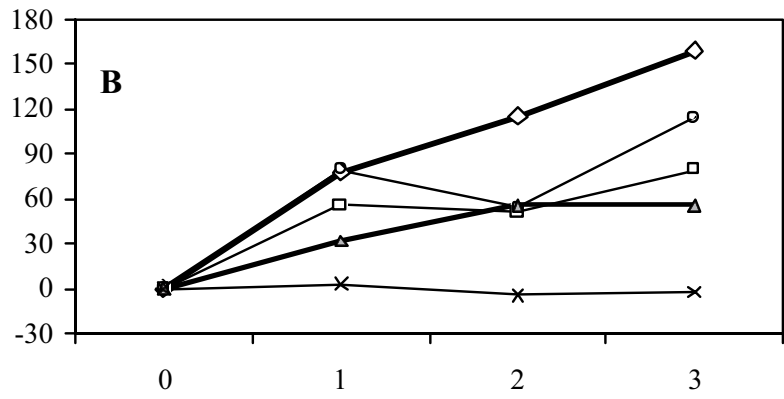

Cycle of Selection

Fig. 3. Response to selection across all five tissue zones over cycles of selection for increased pigment in yellow table beet populations between cycles 0 and 3 $(\mathrm{C} 0-\mathrm{C} 3)$. (A) Gains in betaxanthin as a percent of Cycle 0 (C0). (B) Gains in betacyanin as a percent of $\mathrm{C} 0$.

Table 10. Total dissolved solids distribution in three tissues zones over three cycles of selection, $\mathrm{C} 0-\mathrm{C} 3$, in yellow table beet populations grown at Arlington, Wis., in 1992.

\section{Total dissolved solids (\%)}

\begin{tabular}{lccc} 
Entry & Outer $^{\mathrm{z}}$ & Middle & Center \\
\hline $\mathrm{C} 0{ }^{\mathrm{y}}$ & 10.89 & 10.14 & 9.76 \\
$\mathrm{C} 1$ & 12.45 & 10.8 & 10.86 \\
$\mathrm{C} 2$ & 12.19 & 11.26 & 10.74 \\
$\mathrm{C} 3$ & 13.11 & 11.82 & 11.61 \\
'Golden Boy' & 10.24 & 9.06 & 9.0 \\
\hline LSD 0.05 & 0.91 & 0.97 & 1.07 \\
LSD 0.01 & 1.28 & 1.37 & 1.49 \\
\hline
\end{tabular}

zOuter, middle, and center refer to concentric zones of the beetroot.

$\mathrm{yC}$ followed by a number indicates cycle number.

TDS levels were consistently lower in beets from the second harvest date than the first, however, all TDS differences between planting dates were nonsignificant (data not shown).

CORRELATIONS AMONG ROOT WEIGHT, TDS, AND PIGMENT CONCENTRATION IN YELLOW TABLE BEET. Phenotypic correlations reveal a significant relationship between $\mathrm{BC}, \mathrm{BX}$, and TDS levels at both planting dates (Table 8 ). The correlation between $\mathrm{BC}$ and
$\mathrm{BX}$ was highly positive at both planting dates with $r=0.80$ for the late planting date. Correlations between TDS and BC or BX were also positive and ranged from $r=0.52$ to $r=0.63$ for both populations at both planting dates. The relationship between root weight and $\mathrm{BX}$ was significant in the late planting date $(r=$ -0.34). A negative relationship also exists between root weight and TDS with a more significant correlation present at the early planting date. These inconsistencies between planting dates may be due to differences in root weight between populations and planting dates.

\section{Conclusions}

Simple phenotypic selection has led to significant improvement of both red and yellow table beet populations. Specifically, the selection technique has led to a direct increase in pigment concentration in all tissue zones. Selection in the outer zone has also led to a correlated response to selection in leaf and petiole tissues in both red and yellow table beet populations. Rates of gain in red table beet populations have not plateaued suggesting that alleles that control pigment concentration have not been fixed and further improvement is achievable. Increased pigment concentration resulting from a correlated response to selection suggest that the entire table beet (root, leaf and petiole) could be utilized in commercial applications such as a food colorant or health supplement. At present, pigment extraction technologies cannot accommodate the entire plant in processing operations.

It is unknown whether utilizing selection in all areas of the root would make the selection process more effective and result in roots with more uniform pigment distribution. Rates of gain were higher in the middle and center zone than the outer zone of the red populations using the current strategy illustrating the effectiveness of the current selection strategy to increase pigment concentration throughout the beet plant. In addition, differential pigment concentration throughout the root occurs across populations that are not subjected to pigment selection in the outer region such as 'Big Red' and 'Golden Boy'. Therefore whole root selection may not provide a significantly more effective means of increasing whole root pigmentation than the current strategy. This conclusion is confirmed by the fact that the contribution of each tissue zone to pigment concentration of the whole table beet has remained consistent throughout cycles of selection. Spatial distribution data confirm previous observations that pigment concentration is highest in outer tissue zones. The mechanism behind this phenomenon could range from simple biological to biochemical reasons involving the cell growth pattern of cambial rings or the accumulation of pigment and activation of pigment biosynthetic enzymes in cells nearer to sources of stress.

\section{Literature Cited}

Blackmore, R., F. Nueman, H.D. Brown, and R.C. Burrel. 1942. Relation of fertility levels and temperature to the color and quantity of garden beets. Proc. Amer. Soc. Hort. Sci. 40:545-48.

Goldman, I.L., K.A. Eagen, D.N. Breitbach, and W.H. Gabelman. 1996. Simultaneous selection is effective in increasing betalain pigment concentration but not total dissolved solids in red beet. J. Amer. Soc. Hort. Sci. 121:23-26.

Jones, J.M. 1992. Food safety. Eagen Press, St. Paul, Minn.

Kanner, J., S. Harel and R. Granit. 2001. Betalains-A new class of dietary cationized antioxidants. J. Agr. Food Chem. 49:5178-5185. 
Nilsson, T. 1973. The pigment content in beetroot with regard to cultivar, growth, development and growing conditions. Swed. J. Agr. Res. 3:187-200.

Rapoport, H.F. and R.S. Loomis. 1986. Structural aspects of root thickening in Beta vulgaris L. Bot. Gaz. 147:270-277.

SAS. SAS Inst, Cary, N.C.

Sistrunk, W.A. and G.A. Bradley. 1970. Influence of various field practices on quality of canned beets. Ark. Farm Res. 19:9.

Stafford, H.A. 1994. Anthocyanins and betalains: Evolution of the mutually exclusive pathways. Plant Sci. 101:91-98.

von Elbe, J.H. 1977. The betalaines, p. 29-39. In: T.E. Furia (ed.). Current aspects of food colorants. CRC Press, Boca Raton, Fla.

von Elbe, J.H and I.L. Goldman. 2000. The betalains. p. 11-30. In: G.J. Lauro and F.K. Francis (eds.). Natural food colorants: Science and technology. Marcel Dekker, New York.

Watson, J.F. and W.H. Gabelman. 1982. Seasonal changes and cultivar differences in pigment concentrations and percent dissolved solids in roots of table beets. J Amer. Soc Hort Sci. 107:713-716.

Watson, J.F. and W.H. Gabelman. 1984. Genetic analysis of betacyanin, betaxanthine, and sucrose concentrations in roots of table beet. J. Amer. Soc. Hort. Sci. 109:386-391.

Wettasinghe, M., B. Bolling, L. Plhak, H. Xiao, and K. Parkin. 2002. Phase II enzyme-inducing and antioxidant activities of beetroot (Beta vulgaris L.) extracts from phenotypes of different pigmentation. J. Agr. Food Chem. 50:6704-6709.

Wolyn, D.J. and W.H. Gabelman. 1990. Selection for betalain pigment concentrations and total dissolved solids in red table beets. J. Amer. Soc. Hort. Sci. 115:165-169. 